\title{
The Struggles of the Interculturalists: Professional Ethical Identity and Early Stages of Codes of Ethics Development
}

\author{
Laurence Romani · Betina Szkudlarek
}

Received: 30 June 2011/Accepted: 24 December 2012/Published online: 23 January 2013

(C) The Author(s) 2013. This article is published with open access at Springerlink.com

\begin{abstract}
Ethicalisation processes that partake in the construction of a firm or a professional group's ethical identity are often described as a relatively linear combination of several components, such as policies (starting with the development of a code of ethics), corporate practices, and leadership. Our study of a professional community dealing with the topics related to cultural diversity indicates a more reciprocal relationship between ethical identity and ethicalisation processes. We argue that a tangible form of ethical identity can pre-date the ethicalisation process of a professional group, and additionally, can impact this process at the start. We highlight that, despite the absence of official ethical statements in the community, a form of ethical professional identity is already present among the interculturalists of the international organisation Society for Intercultural Education Training and Research. Using critical discourse analysis, we identify the proclaimed humanist ethos in the discourses that interculturalists co-produce and diffuse during conferences, on on-line discussion forums, and in the mission of their professional organisations. This study contributes to the literature on ethical identity development by showing how a pre-existing form of ethical identity can influence the early stage of the development of a code of ethics. In addition, we indicate that, similar to organisational identity construction, ethical identity construction
\end{abstract}

\footnotetext{
L. Romani $(\bowtie)$

Centre for Advanced Studies in Leadership, Stockholm School of Economics, P.O. Box 6501, 11383 Stockholm, Sweden

e-mail: laurence.romani@hhs.se

B. Szkudlarek

University of Sydney Business School, H10-Storie Dixson Wing

Building, Sydney, NSW 2006, Australia

e-mail: betina.szkudlarek@usyd.edu.au
}

uses self-other identity talks, thus, defining an ethical other (or less ethical other) in its development.

Keywords Code ethics development - Ethical identity . Cross-cultural · Intercultural · Professional community · Responsibility

\section{Introduction}

How can we strengthen an organisation's or a professional community's ethics and ethical behaviour? Early answers to scandals and misconducts have focussed upon reducing unethical behaviour with the elaboration of codes of conduct. The efficiency of such business policies turned out to be limited, as the case of Enron reminds us: an organisation with a very well-crafted code of ethics. In addition, the reduction of unethical practices does not, in itself, create an ethical identity. Codes need to be enacted, to be alive in the organisation or the professional group: they need to be what Verbos et al. (2007) call 'living codes of ethics'. This way they can lead to an organisational ethical identity: in short, an ethical organisation. Current literature on the 'ethicalization' process (Fukukawa et al. 2007) of firms or professional groups details additional components that take part in the development of a firm's ethical identity (Gray and Balmer 2001). Organisational culture, processes, strategy, and leadership are some of them. Yet, it is argued that the code of ethics remains an essential and initiating component of this process (Verbos et al. 2007; Webley and Werner 2008). In other words, a code of ethics is assumed to precede and prime ethical identity.

This study, however, reveals the existence of an ethical identity prior to the initiation of an 'ethicalization' process (Fukukawa et al. 2007) of a professional community. The 
community we studied is the emerging professional group of 'interculturalists' (Dahlén 1997). Interculturalists are trainers, consultants, teachers, or other professionals working with the theme of cultural differences or cultural diversity. We study interculturalists in the context of the Society for Intercultural Education Training and Research (SIETAR): the largest community of cross-cultural experts of about 2,500 official members worldwide (Berardo 2008).

Our qualitative investigation paid special attention to the ethical struggles of the interculturalists when discussions about ethics took place, and when a consultative process for the ethicalisation of the community started under the initiative of SIETAR USA. Extant literature on code of ethics argues the benefits of a participative process in code development. Employees in organisations and professionals in communities are expected to engage with the document: to take part in its development to improve its relevance and effectiveness (e.g. Schwartz 2002; Snell and Herndon 2004; Kaptein and Schwartz 2007; Webley and Werner 2008; Painter-Morland 2010). In turn, relevant codes of ethics are said to participate in the development of organisational ethical identity (Verbos et al. 2007). Our study centres on the very first steps in the ethicalisation process of the professional group: when interculturalists express the ethical struggles they face in their professional duties and, thereby, start a discussion around these dilemmas and the values they stand for (see Messikomer and Cirka 2010).

The ethical struggles that came to be discussed revealed surprising stances regarding the professional responsibility interculturalists felt towards their clients. Responsibility towards the client is a central theme in the majority of codes of ethics (Gaumnitz and Lere 2002; Schwartz 2002, 2005). In the intercultural community, this theme seems to be a challenging one. Some of the professionals discussed their uneasiness with serving their clients' needs; others felt very limited responsibility towards their clients. This is intriguing since most interculturalists are running independent businesses and live off a commercial relationship with their clients (Berardo 2008).

When we investigated the origin of these struggles, it became progressively clear that they are linked to an existing professional ethical identity of the group: a professional identity that, for some, is formed in opposition to their clients. This professional identity tends to present the interculturalists as human(ist) and their clients as instrumental(ist). We analysed the collective conversations in which the humanist ethos of the interculturalists is expressed and found it particularly in self-other identity talks (Ybema et al. 2009). In these talks, the interculturalists seem to collectively construct their ethical identity in opposition to another, and for some, a less ethical other.
The other to which they are referring is the corporate context: that is to say, their potential clients. We argue this provides one of the explanations of the ethical struggles some interculturalists face regarding responsibility towards the client.

Interestingly, this professional ethical identity is not explicit in the sense that there are no official statements regarding the ethical stance of this community, no statements about ethical principles, and no professional code of ethics. However, we show that this professional ethical identity is sufficiently tangible in collective conversations to influence the struggles that interculturalists say they face in their professional activities; we know that the expression of these struggles is the very first step in participative code of ethics development (Messikomer and Cirka 2010). In brief, this form of ethical identity can influence the development of a code of ethics, which is an important aspect of the ethicalisation process. Thus, there seems to be a reciprocal relationship between ethical identity and code of ethics.

This article contributes to the ongoing conversation about the ethicalisation process of organisations or professional groups; its primary contribution touches upon the emergent topic of the relationship between ethical business policies, such as a code of ethics and the ethical identity of a professional group or an organisation. Ethicalisation is perceived as a process with some forms of argued linearity, especially regarding the necessity to have ethical business policies to create an organisational ethical identity. Our study of the professional group of interculturalists contributes by shedding new light on this process. First, it reveals that there is a form of ethical identity prior to the development of a code of ethics. Second, this ethical identity may influence the development of a code of ethics in unexpected ways: for example, with regard to topics related to responsibility towards a client organisation. In brief, the major contribution of this study is to reveal that the relationship between code of ethics and ethical identity can be more reciprocal than currently argued in the literature.

The second contribution of this article touches upon ethical identity construction. Extant literature on ethicalisation tends to argue that a professional group or organisation becomes virtuous and builds its ethical identity by acting virtuously and being led righteously. We provide evidence that this process is most certainly coupled with the presence of another process known in the literature on organisational identity construction: self-other identity talks (Ybema et al. 2009). We show that self-other identity talks or differentiation talks (talks about who the group is not) in organisational identity construction are also a part of ethical identity construction. The studied community appears to establish a (less) ethical other in building its own 
ethical identity. These talks, articulating the ethical identity of a group in terms of opposition, add to the process of defining aspirational virtues (Weaver 2006).

\section{From Codes of Ethics to Ethical Identity}

\author{
Why Would a Professional Group Develop a Code \\ of Ethics?
}

In their overview of the development of codes of ethics, Messikomer and Cirka (2010, p. 57) explain that the development of codes for corporations in North America has been a process influenced by the discovery of misconducts and the rise of scandals. Prescriptions written in reaction to misdeeds tend to produce 'low road' codes of ethics. They address ethical issues in legalistic terms, with lists of prohibitions and restrictions. In contrast, 'high-road' codes of ethics focus upon social ethics and doing the right thing. They are proactive and often stand for managerial commitment (Rezaee et al. 2001). Fukukawa et al.'s (2007) synthesis of the contributions of their special issue on the interface between business ethics and corporate identity states that the initiation of an ethicalisation process is always triggered by one of these three stimuli: leadership, strategic positioning, or external forces.

The trend of code writing has grown since the 1970s and spread among corporations, occupational groups, and professional associations across the world; however, it remains a phenomenon that is most strongly present in the North American context. For example, there are cross-national differences in regard to how common it is to have corporate or professional codes, or between content and range of applicability (Singh et al. 2005; Matten and Moon 2008; Barmeyer and Davoine 2011).

Codes of ethics, codes of conducts, or codes of professional or corporate responsibility come in a variety of names and content; they primarily consist of moral standards to guide employee, corporate, or professional behaviour (Stevens 1994, 2008; Schwartz 2002; Webley and Werner 2008). Literature on codes of ethics has developed from a concern about a code's content to an assessment of a code's effectiveness (Mathews 1987; Cleek and Leonard 1998; Adam and Rachman-Moore 2004; Kaptein 2011). Content, development process, and the corporate environment in which the code is implemented progressively emerged as playing a role in its effectiveness.

\section{Code of Ethics Content}

Helin and Sandström's (2007) review of the literature on corporate codes of ethics organises content-oriented studies into four main groups. Some studies focus upon comparisons within or across countries (e.g. Langlois and Schlegelmilch 1990); others emphasise differences between industries (e.g. Montoya and Richard 1994) or ethical challenges (for example, bribery in Gordon and Miyake 2001). Another group addresses specific forms of organisations: for example, professional groups. Gaumnitz and Lere (2002) identify major content categories of codes of ethics of professional business organisations in the United States. Confidentiality was found in $100 \%$ of the reviewed codes. Honesty and integrity, as well as responsibilities to employers or clients could be found in more than $90 \%$ of the cases. Obligation to the profession and independence and objectivity was in more than $80 \%$. These categories are not only representative of relevant issues for the professional groups but also necessary for a code to be ethical. This is presented in Schwartz's $(2002,2005)$ investigation of core moral values demonstrating that the content of codes of ethics should include trustworthiness, respect, responsibility, fairness, caring, and citizenship.

Gaumnitz and Lere (2002, p. 42) explain that, in codes of ethics, responsibility is first articulated as responsibility of the firm to its employers/clients. The most common ethical requirement is the obligation to "faithfully execute responsibilities' (60\%). For example, 'A member shall not fail to use his or her full knowledge and ability to perform his or her duties to this client (...)'. Another expression of responsibility most frequently found in the surveyed codes is 'to support the objectives of the client' or 'obligation to not coerce, aid, or abet unethical behavior' (Gaumnitz and Lere 2002, p. 43).

\section{Code of Ethics Effectiveness}

The efficacy of codes of ethics is a debated topic, with positions arguing that firms cannot be ethical or that codes' effectiveness is contingent. Following Emmanuel Lévinas, some theoreticians of business ethics argue the impossibility of defining morality in a collective, legalistic form (e.g. Bevan and Corvellec 2007; Jones 2003). Individuals, not collective entities, can execute autonomous moral decisions, because only individuals meet the condition of humanity and autonomy of action (Bevan and Corvellec 2007). If collective morality is unattainable, documents such as codes of ethics are futile. Moreover, in the views of Derrida or Lévinas, the moment we translate ethics into a strategic business objective or tactical intention, the instrumentality of this action denies it legitimacy in moral terms (see Jones 2003). Therefore, this position sustains that ethics cannot be simply translated into a set of logical rules or laws, to be followed universally across the organisation (Munro 1998; Jones 2003). 
Taking the above concerns into consideration, some scholars attempted to redefine both our understanding of effectiveness and the role of codes of ethics. The focal point is no longer the code itself; it is individuals' relationship to the code. Ten Bos (1997) argues that, while an ethical dilemma cannot be resolved by applying a uniform rule, such rules do not necessarily lead to moral apathy or procedural obedience. Independent agents in the process of relating to any given rule make a conscious choice as to whether they obey the rule and in what way they should translate its application in a given context (ten Bos 1997). This decision-making process is, in itself, a moral act. Moreover, codes of ethics create effects beyond those intended by the creators. Efficiency of such documents has traditionally been defined in terms of intended impact and predefined dilemmas; yet, there are also unintended effects that can have moral consequences (see, e.g. Jensen et al. 2009). In consequence, as an alternative to traditional codes of conduct, Painter-Morland (2010, p. 265) recommends what she calls 'questioning kind' of codes. These codes foster a relationship between the text and the individuals by opening up a continuous quest for queries and exploration of doubts, and an ongoing ethical questioning of where the organisation is headed. In sum and to put it simply, to the argument that codes as such cannot be efficient, some answer that ethics lie in employees' relationship to the code, thereby, placing employees in a more central position regarding code of ethics.

\section{Codes of Ethics and Employee Participation}

The focus upon process of code creation and implementation resonates in numerous empirical accounts. For example, Helin and Sandström (2010) show that the signing of the code can be, in itself, an empty declaration, or even a result of rejection of its content and distancing from it (see also Barmeyer and Davoine 2011). Therefore, the process around the implementation of such artefacts is critical for employee involvement with the code (Helin and Sandström 2008). Schwartz's (2004) study of code users' perceptions provides indication of desirable content, creation, implementation, and administration of corporate codes of ethics. For example, employee participation in the development of the document leads to a more realistic and pertinent content, which can make the code company-specific and, therefore, relevant (Olsen 2004). By ensuring the appropriateness of the examples and situations addressed in the code, employee participation in the development process contributes to code content that, in turn, can benefit the employees' relationship to the code and to its effectiveness (Kaptein and Schwartz 2007).
Few studies specifically address the development process of the code of ethics. The work of Kaptein and Wempe (1998) is an example of the empirical investigation of the development of the code of ethics for the Schiphol airport (in the Netherlands). The authors present dilemmas that organisations must solve in the development process: the very first being the degree of involvement and participation of employees. Employee involvement in the code development process progressively emerged as one of the conditions for the creation of a code of ethics enacted in the organisation (see Snell et al. 2004; Verbos et al. 2007; Webley and Werner 2008; Schwartz 2002).

Messikomer and Cirka (2010) provide a first-hand empirical investigation of the development of a code of ethics for the professional organisation of senior move managers. They show how a code of ethics is successfully built with a development process that is participative, led by ethical managers, and value-based. This is in line with Newton's (1994) framework for ethical validity. The process development of a professional code of ethics described by Messikomer and Cirka (2010) starts with participation. During well-attended workshops, participants first ponder their own perceptions of ethics and core professional values. Through successive workshops, they reached a consensus regarding the core values to be included in the code of ethics. In practice, the very first step in this process was the participants' reflection upon their experience, writing down personal accounts of ethical dilemmas they encountered in their professional work, and how these were resolved. Debriefing highlighted the different perceptions of what is an ethical dilemma and which values were at stake. These values are then the ones upon which the code of ethics builds (Messikomer and Cirka 2010, p. 61).

\section{Living Code of Ethics and Ethical Identity}

Stevens' (2008, p. 605) synthesis of previous literature on code effectiveness highlights the decisive interrelated influence of cultural values and communication: 'Ethical codes require thoughtful absorption and discussion [by employees] in order to become culturally embedded' and consequently enacted. Managers, leaders, and employees' involvement with the code and their participation in the creation process and discussion are argued to be essential to embed the code in the corporate culture. In other words, having a relevant code of ethics is necessary, but a 'living code' is what makes organisations ethical. A living code of ethics is a code embedded in the organisational culture and internalised by its members (Verbos et al. 2007; Webley and Werner 2008).

Webley and Werner (2008) posit that a well-designed code of ethics together with managers' exemplary behaviour creates and promotes an ethical organisational culture. 
Verbos et al. (2007) complement this by adding that this ethical organisational culture, together with processes (recruitments, rewards, etc.) and authentic leadership (moral awareness and capacities of leaders) translates into a living code of ethics. They specify that this living code is then at the origin of the organisation's ethical identity. In sum, managerial commitment, leadership, culture, and strategy are elements that take part in the enactment of a code into a living code of ethics and contribute to the development of an organisation's ethical identity. Messikomer and Cirka (2010) have argued that similar mechanisms are at play for professional ethical identity construction.

The concept of ethical identity is argued to be applicable to professions and the corporate world alike (e.g. Weaver 2006; Gray and Balmer 2001). While some challenge the assumption that organisations have their own identity or can act as conscious moral agents (Ashman and Winstanley 2007), other authors have developed the concept of ethical identity as 'the set of behavior, communications, and stances that are representative of an organisation's ethical attitudes and beliefs' (Berrone et al. 2007, p. 36).

Fukukawa et al.'s (2007) framing of the concept of organisational ethical identity argues for a necessary distinction between the company rhetoric in terms of its espoused values and ethical stance, and its actual behaviour. The idea is to differentiate between the mere presence of ethical policies, for example, and organisations with a living code of ethics. Berrone et al. (2007, p. 36) suggest encompassing the notion of corporate revealed ethics (firm's communication of ethical beliefs) and corporate applied ethics (firm's actual behaviour: actions and policies that can be considered as ethical) into the definition of corporate ethical identity. Some studies centre on revealed ethics (e.g. Haniffa and Hudaib 2007); others chose to investigate both revealed and applied ethics and their link with, for example, firms' performance (Berrone et al. 2007; Baker and Roberts 2011).

\section{Ethical Identity and Organisational Identity Literature}

Professional ethical identity is a concept positioned at the crossroad of the literature on professional groups' ethics (e.g. Winter 2011) and professional groups' identity (e.g. Pratt et al. 2006). Few authors specifically address the ethicalisation process of an emerging professional group the way Messikomer and Cirka (2010) do. Generally, the theoretical framework that is adopted is the one of organisational or corporate ethical identity (e.g. Balmer et al. 2007; Berrone et al. 2007), which itself principally building upon the literature on corporate identity (e.g. Balmer and Soenen, 1999) and organisational identity (e.g. Verbos et al. 2007).
Since the seminal work of Albert and Whetten (1985), research on organisational identity has developed into a flourishing domain addressing not only the core aspects of the construct (central, distinctive, and enduring elements of the firm) but also its impact on, for example, organisational change (e.g. Chreim 2005; Martins 2005) or relationships with stakeholders (Brickson 2005). Among the core elements of organisational identity are the distinguishing attributes of the firm that set it apart from other organisations (Whetten 2006, p. 223). These distinguishing attributes are also 'distinguished' in the sense that they refer to an ideal view of the organisation (see Czarniawska 1997): for example, the ideal hospital or restaurant.

In the organisational identity literature, the stream addressing organisational identity construction brings attention to how employees differentiate their organisation with the use of self-other talks. Ybema et al. (2009) argue that self-other identity talks appear in corporate identity literature to be the critical ingredient in the process of identity construction. 'Identities emerge through the articulation of similarities and differences. (...) An intrinsic part of the process by which we come to understand who we are is intimately connected to notions of who we are not and, by implication, who others are (and are not)' (Ybema et al. 2009, p. 306). For example, the coaches studied by Clegg et al. (2007) constantly define themselves in terms of what they are not (i.e. consultants).

While the discourses of distinctiveness are identity defining, they are never neutral. The categories used to define one's organisation or ones' professional group tend to be positive. For example, Mahadevan (2011) reveals how engineers on the main site of an organisation differentiated between themselves and other engineers working in the Indian subsidiary. They referred to themselves as the 'experts' and to the others as the 'young and pushy' (Mahadevan 2011, p. 97). In this study, we found the stream of research on organisational identity construction relevant to lend insight into organisational or professional ethical identity research.

\section{Towards an Ethical Identity}

The various elements of code of ethics, employees' engagement, leadership, organisational culture, living code of ethics, and ethical identity all take part in the creation of an ethical organisation. Webley and Werner (2008) explain that an ethical business policy and an ethical corporate culture are closely intertwined. The code can be the expression of the culture of an organisation. The code can be seen particularly as an inspirational example for employee behaviour; it can provide 'insight into the kind of ethical culture to which the organisation aspires. Therefore, it is important to get the design of such policy right' 
(Webley and Werner 2008, p. 410). Although code and culture are intertwined, the authors believe in the primacy of the code to culture. Similarly, Verbos et al. (2007, p. 20) argue that a living code of ethics primes ethical identity salience.

On the basis of extant literature and the above review, we can summarise the relationship between the various elements contributing to an ethical identity. Perceived individual dilemmas are discussed collectively and this conversation results in the mapping of core values. These core values are a part of the code of ethics content development (e.g. Messikomer and Cirka 2010). This code is relevant because its content is based upon employees' views (e.g. Schwartz 2004), because employees have participated in its development (Schwartz 2002) and also because it provides codifications and sets of expectations on which employees can act ethically, by choosing a particular attitude with respect to this code (ten Bos 1997; Jones 2003; Painter-Morland 2010). This code is enacted by a committed management team and integrated into the corporate strategy to form an ethical organisational culture (e.g. Webley and Werner 2008). This organisational culture, together with organisational processes and authentic leadership, is what sustains a living code of ethics and, as a result, an ethical organisational identity (e.g. Verbos et al. 2007), if such thing is possible (Bevan and Corvellec 2007).

In sum, and as currently argued, the link between a code of ethics and an organisational or professional ethical identity is long and requires several conditions and complementary elements. We will show in our study that the link between a code of ethics and ethical identity is more direct and reciprocal. The study presented in this article builds upon the case of a participative process for code of ethics development with the ambition of developing a living code of ethics for the professional community of interculturalists. This participative process starts with the discussion of ethical struggles that practitioners face in their activities (Messikomer and Cirka 2010). Therefore, we will centre our case description on the presentation of the ethical struggles voiced by the interculturalists. We concentrate upon the theme of responsibility: one of the core topics of code of ethics content (Gaumnitz and Lere 2002).

\section{Research Process}

An in-depth qualitative investigation of the intercultural community that took place between 2007 and 2012 provides the empirical support for our claims. Our research aimed to investigate the professionalisation of the community and its struggles. This article presents our analysis of the struggles related to ethics and responsibility.
Methodology

We focus upon the ethical struggles expressed by interculturalists in workshops or on on-line forums; this is the very first step of the code of ethics development as described by Messikomer and Cirka (2010). As the expression of struggles will translate into a process, this provides an illustration of what Chouliaraki and Fairclough (1999) posit as a central tenet of discourse analysis, namely that discourses and social practices are mutually constitutive. Our methodological positioning is inspired by critical discourse analysis (e.g. van Dijk 1997, 2001; Wodak and Meyer 2001, 2009). We consider a discourse to be both written and oral texts that are in a dialectical relationship between discursive events, situations, institutions, and social structures that frame them (see Fairclough and Wodak 1997, p. 258). We see critical discourse analysis' specificity in its agenda to address power inequalities, its demand for researchers' reflexivity, and its sensitivity for social and cultural contextuality and intertextuality.

In the spirit of the pragmatic model of critical discourse analyses outlined in Vaara and Tienari (2004) and Fairclough (2001), we used an inductive and emergent interpretive approach (Alvesson and Deetz 2000). Originally concerned with the 'social problem' (Fairclough 2001) of interculturalists' ethical struggles, we progressively refined our research question to why ethical struggles regarding responsibility were articulated in opposition to the interculturalists' clients. The discursive event we consider is the voicing of these struggles by interculturalists, with a focus upon the genre of collective oral and written conversations. We collected a wide range of material and texts using indepth qualitative methods (semi-structured interviews, conversations, participant observations, and documentation) that provide the basis for contextual and intertextual understanding.

Investigation

SIETAR organisations are forums of exchange of knowledge, practices, and perspectives on how to train intercultural communication and cross-cultural management. These are meeting points of three areas of intercultural work, namely education, training, and research (Roth 2009). SIETAR is a well-organised and active community; its events are the venues for interculturalists to present and exchange knowledge and experiences regarding work methods, concepts, ideas, and products. Therefore, SIETAR is not a place; rather, it is a network (Dahlén 1997, p. 26) and its investigation requires multi-sited fieldworks (Marcus 1995) in physical and virtual places.

We participated in numerous community events in Europe and the US, conducted semi-structured and 
unstructured interviews, as well as followed several discussion forums. We aimed for maximum differentiation (Agar 1996) in the profile of our interlocutors and gathered information from both individuals and groups. This was necessary to become aware of the social identities of the interculturalists and the relationship between groups of people that take part in the conversations on ethical struggles. Our material consists primarily of the transcription of notes from more than 60 exchanges (ranging from $20 \mathrm{~min}$ to three-and-a-half hours) and from participant observations in 16 co-located or virtual trainings for trainers (ranging from $1 \mathrm{~h}$ to 5 days) and 10 conferences or workshops (average duration of 2 days). Extensive field notes (Emerson et al. 1995) were taken throughout the events.

The second source of insights used in this investigation comes in the form of computer-mediated discourses (Herring 2001; Yates 2001) such as online discussion forums (Yahoo discussion group, Linked-in conversations, and SIETAR 'Eye on Ethics' web forum). We followed conversations taking place within the community and particularly the Linked-in forum of SIETAR Europa: 'Competence in intercultural profession' and two discussions within it: 'Professional intercultural certification' (MarchSeptember 2010) and 'Decolonizing Intercultural Practice' (DIP) (June-October 2010). These mostly informal conversations involved a diversity of participants, some very well-established interculturalists (with their own tools and certification workshops), and other apparently simple actors in the SIETAR network. One of the authors purposefully made an entry in a conversation to collect contributions from the community regarding professionalisation; we made an entry together in the Eye on Ethics web forum. In other words, we took advantage of the complementary form of information and informants that can be gathered with social network (Murthy 2008), and the written and durable format of the contributions that are explicit in their formulations and in the development of the arguments (Herring 2001). Adopting King (1996) guidelines, we only reproduce here the voices of those who granted us consent.

The third source of insight includes training materials circulating among interculturalists, newsletters of SIETAR USA, UK, France, and Deutschland, publications by SIETAR Europa and SIETAR Deutschland, academic and non-academic publications of SIETARians, and academic research on the interculturalists and intercultural training. This was necessary to put the discourses into a historical and ideological perspective. In other words, we wanted to situate the collective discourse in a broader context and in view of other texts. In addition, this helped us to clarify the social and the professional status of the voices we heard and to identify the power inequalities in the community.
Negotiated Identities

Both of us are SIETAR members belonging to several intercultural communities, and are actively involved in intercultural work for private and public organisations. Our introduction to the community was through SIETAR France (2010) and Young SIETAR (2007) with the agenda to know the interculturalists both from a knowledge packaging and a professionalisation perspective, respectively. From the onset, our position in SIETAR has been one of insiders with an agenda of investigating the community stated from the start. In spite of this, our identity as cross-cultural management trainers was the one to which most of our interlocutors related: both in conferences and in training sessions. We found ourselves with contradictory personal commitment a few times: for example, when we attended both as a researcher and a trainer events such as trainings for the trainer. We resolved them with what Marcus (1995) calls 'circumstantial activism', meaning that we renegotiated our identity of researcher or trainer in function of the site of investigation.

\section{Analysis}

Our investigation of the ethical struggles paid attention to their expression (content and form), obstacles to the resolution of the struggles and those who benefit-in the current social order-from these struggles and their (non) resolution (see Fairclough 2001). The interaction analysis model (see Gunawardena et al. 1997; Marra et al. 2004) inspired our analysis of the online discussion DIP. We independently organised our field notes after each event (conference or discussion) into first-order categories relating to content topics, interlocutors, and reactions. Shortly afterwards, we discussed and compared these categories, refined them, and developed sub-interpretations (Alvesson and Sköldberg 2000). We made use of the model developed by van Leeuwen and Wodak (1999) in our analysis of the collective conversations (particularly, on-line forums and conference sessions). We searched for voices of authority, the rationalisations in use, ideologies, and dramatisation.

In subsequent events, we confronted our interpretations with the field and revised them. Our participant observations also aimed to gain feedback from interculturalists on our emerging interpretations. We did so through discussions with practitioners of different profiles, with interculturalists dealing with ethics, and with the initiator of some on-line conversations. Our entry in the SIETAR USA web forum 'Eye on Ethics' presented preliminary findings of our investigation (Romani and Szkudlarek 2011). Our last two participant observations confirmed the relevance of the interpretations that we had gradually developed in this iterative research process. 


\section{The Interculturalists of SIETAR}

The case focuses upon the ethical struggles expressed by the interculturalists of SIETAR. We found that, depending upon the experience of the interculturalists and the kind of clients they have, the struggles they voice are very different. Although members of the community have some important traits in common, we propose four different ideal types of interculturalists that highlight their social profile and acknowledge the internal differences within the community.

\section{The Interculturalists}

The terminology 'interculturalist' is borrowed from and builds upon Dahlén's (1997) investigation of consultants, trainers, and coaches that deal with culture and cultural differences. This heterogeneous group of people forming SIETAR was surveyed by Berardo (2008) who aimed to present a comprehensive picture of the community. The majority of professionals reside in the US, with a strong representation also found in Europe and Asia. Almost $80 \%$ of interculturalists are women with a background in the humanities. Interculturalists work across different ranges of industries and within different sectors, including private $(65 \%)$, academic $(45 \%)$, non-profit (29\%), and public (18\%) (Berardo 2008). Most interculturalists work as independent contractors and deliver training, coaching, or consulting services to their corporate clients. Berardo's survey confirms the self-perception of the intercultural community (e.g. Scheitza 2009) and the portrait painted by Dahlén in 1997.

The heterogeneity of the community is one of its characteristics. We realised in our investigation that interculturalists' experience in the field, and the nature of client they want to address, influence the sort of ethical dilemmas they express. We chose to organise these interculturalists into four types: Entrepreneurs, Gurus, Activists, and Professors. These profiles are ideal types, meaning they belong to a classification that organises the complexity of the community; no interculturalist would fit perfectly into one single profile. These ideal types enable us to highlight the relationship between groups of interculturalists involved in the conversations and the power inequalities between them.

We call entrepreneurs interculturalists that are new to the field and willing to address the needs of corporate clients; for example, they sell pre-departure or repatriation trainings. We call the other junior interculturalists the activists: those oriented towards public clients such as municipalities or various NGOs. For example, they train social workers on issues such as cultural differences and discrimination; they also prepare students to spend a term abroad. We, the authors, mostly fit this profile. We call those senior interculturalists who are very successful in their orientation towards corporate clients the gurus. This means they serve as an inspiration or a reference on how to conduct an intercultural business. Finally, we call those senior interculturalists that address public clients, the professors. This is done as an indication of the wellestablished position and symbolic authority they have; they also tend to be associated with institutions of higher education.

\section{SIETAR and Collective Conversations on Ethics}

SIETAR's work with ethical standards seems coupled with its professionalisation efforts (Dahlén 1997). We witnessed at the SIETAR USA congress in 2007 a discussion for the development of a code of ethics, on the basis of a participative and consultative process. Despite our repetitive attempts, we could not access the documents produced at that time. The efforts made towards the development of a code of ethics were linked to the initiative of members (entrepreneurs and professors), rather than being a reaction to external forces or known misconduct. To our knowledge, the attempts initiated in 2007 were put on hold due to the difficulty in achieving consensus on ethical conducts perceived valid through the variety of cultural environments represented in SIETAR.

Conference sessions organised in SIETAR USA and Europa are recent initiatives regarding ethics, notably, the SIETAR USA topic forum on ethics with the ambition to 'develop a coherent and effective approach to ethical standards within the profession' (SIETAR USA 2011 Fall Newsletter 12, p. 2). SIETAR USA has devoted part of its newsletters in 2011 and 2012 to the forum 'Eye on Ethics' by inviting contributions from the intercultural community. The first article, written by a guru interculturalist argued for the necessity to adopt a code of ethics for strategic reasons, to provide a competitive advantage to 'ethical' interculturalists. Other pieces addressed frequent discussion topics within the community, such as cultural relativism, moral awareness, or the need for a code of ethics in the professional community. These contributions were written by gurus and entrepreneurs. In addition, monthly entries were added to the online version of the forum on SIETAR USA's webpages (November 2011-September 2012). They touch upon topics such as the competitive advantage of having a code, the benefit of ongoing conversations on ethics, ethical praxis or ethics, religion, and cultures. All the interculturalist profiles are represented among the authors.

Although conference sessions on ethics are very well attended, the web topic forum triggered no recorded comment. This is in stark contrast to our experience of the 
readiness and promptness of interculturalists to raise ethical issues and start spontaneous conversations about these issues. However, a discussion related to the forum was initiated in May 2012 on one of the interculturalists' mailing lists [Intercultural insights]. This prompted quick reactions. Some of the first questions raised concerned the purpose and agenda of developing such a code, and the difficulty of having a code that can be relevant in a diversity of situations and cultural contexts that the interculturalists face. In sum, the SIETAR community is familiar with discussion topics related to ethics and ethical struggles. From our experience, interculturalists are keen on engaging in such conversations and can link them to aspects that influence what is perceived as 'ethical' in various cultural environments.

\section{Collective Conversations About Ethics: Our Focus}

Upon Responsibility

Some themes recur in collective conversations about ethics. An example is whether it is ethical to work for a client selling weapons or tobacco, or what to do when the trainer thinks that information shared during the meeting should not 'stay in the room' and should be reported to HRM or trainee's supervisors. What is noteworthy is that the profile of the interculturalists influences the issues with which they are dealing. For instance, gurus face issues of plagiarism or unauthorised use of their material, while young entrepreneurs talk about the necessity to accept insufficiently paid training to build a client portfolio, although this is a disservice to the profession. In contrast, professors may raise issues of (mis)representation of the 'cultural other' that is done with an oversimplified application of cultural dimension frameworks, such as those of Hofstede (1980), Trompenaars (1993), or Lewis (1996).

One of the sessions at the SIETAR USA conference in 2011 aimed to identify interculturalists' specific ethical challenges. Participants were asked to describe and discuss in small groups ethical dilemmas they are facing. In line with our previous observations, the topics that surfaced included issues of plagiarism, confidentiality, cultural relativity of ethics, and responsibility towards the client. Summarising her group discussion, entrepreneur Mary said: 'To whom are we responsible? And where does our responsibility stop?' She then resumed a long-standing discussion in the community and touched upon two of its most challenging aspects.

In this article, we chose to address the ethical dilemmas around responsibility for three main reasons: first, the theme of responsibility towards the client is vital to the development of a code of ethics since it is both part of many codes' content (Gaumnitz and Lere 2002) and a necessary theme to have in order for the code to be ethical
(Schwartz 2002, 2005). Second, the issue of responsibility is not straightforward for interculturalists since their clients are not necessarily the beneficiaries of their service. Consequently, this is a sensitive topic in the community, which will need to be addressed in the development of a code of ethics. Third, we noticed that discussions around issues of responsibility spontaneously take place among interculturalists in a variety of settings (informal discussions, trainings, conference sessions, and on-line discussions), and trigger lively debates between entrepreneurs, activists, and gurus. As for professors, their position and the nature of their audience may explain why they do not seem to contribute much to the conversations on responsibility towards clients, yet contribute more strongly to conversations on other topics (e.g. the 'Decolonizing Intercultural PracticeDIP').

\section{Responsible to Whom? And Where Does Responsibility Stop?}

As interculturalists, when we know our work could potentially put someone in the 'mobile effect' [be a transformational experience and dramatically change their view of the world], don't we have some responsibility to them? Deborah Orlowski, professor (Eye on Ethics, 2012 Web forum entry).

Interculturalists offer programs that focus upon interpersonal growth, transformational change, intercultural awareness, and sensitivity (Berardo 2008). These processes can be time-consuming as conditions for openness, trust, and feeling of security can be demanding; however, they are necessary conditions for participants to engage in transformative processes. In addition, these processes are not necessarily measurable or may not have immediate implications for the life of the trainees or their work in the organisations. This leads to the first struggle regarding responsibility that is discussed in the community: responsibility to use 'one full ability to perform' (Gaumnitz and Lere 2002, p. 42)

\section{Responsibility Towards Content and Performance}

As described in Berardo (2008), the first challenge of the community is to establish return on investment on intercultural training. The trainers need to find compatibility between the organisational contingency (goal, budget, availability of participants, or measureable impact on employees), efficiency, and intercultural ideas of dialoguebuilding or transformational learning. Corporate conditions, or believed corporate conditions, often demand that interculturalists renegotiate their views and provide training that 
does not match their ideas of what is needed for personal development. A trainer (guru) in the SIETAR Workshop on 'the business of intercultural business' (2011) addressed the dilemma raised by one of the participants: 'Two hours in front of a group is better than nothing, (...) even if you don't think that you can do something impactful in less than one day'. Some interculturalists adjusted their views in light of a perceived demand of the corporate environment and no longer consider their ideal training design as a reference. Instead, their reference point is the absence of training:

Previously, when someone asked me to do a one hour [relocation] training over telephone, I would have said 'no way', but now I am aware that this might be the only chance I have to talk to and be helpful to these people Aimée, entrepreneur.

Interculturalists' views on what is desirable for clients and which training they should follow is, therefore, first challenged by the corporate context' limitations regarding time, availability, or budget. In practice, interculturalists' views on an ideal content may vary strongly. Some like to use cultural dimension models or instruments to measure intercultural awareness; others use critical incidents, roleplay, or literary analysis. However, independently of their preferences, they join in conversations about their perception that the corporate context's priorities or concerns impact their training content.

\section{Responsibility Towards Your Own Business}

Some interculturalists feel that they need to renegotiate their views and compromise their ideal training design. This bargaining often determines the signing of the deal and, consequently, the survival of the intercultural business. This struggle and the way in which to address it was a part of the DIP discussion.

[...] First and foremost, I seek to meet my clients' needs. I am a business; I want to grow [...] I bring awareness, debate, and self reflection on equity and justice into my training sessions, but I also have an eye on my bottom line [...] Martha, entrepreneur (DIP)

The interculturalists must find a way to combine their agenda and that of the corporate client. Our impression is that this tension is most strongly felt by the entrepreneurs and the activists who address corporate clients. The strategic priorities of the organisation cannot be overlooked since the corporation ultimately buys the services. Consequently, the struggle the interculturalists face is whether to sell what they may see as an imperfect product, or not to sell at all. Some see the solution of this dilemma in a longterm relationship with the firm

If this is my first time to work with this client and they have got a mind-set about design that is not going to destroy the program, I am going to seize it. I am going to design that program and, through that effort, I am going to help win them over on where I think is the next level they should go to in the design. A trainer in a group session, Intercultural Communication Institute training 2007.

This strategy can potentially lead to establishing trust and professional freedom gained by the interculturalists in their corporate relationships. Several interculturalists of the guru or professor profile stated that their clients give them the autonomy to design and deliver training; therefore, they did not feel restrained in their views of an ideal product. In brief, it seems that the challenge of adapting the perceived ideal training's form and content is foremost felt by entrepreneurs and activists. We see in the discussions of these challenges that the reactions are diverse: from attempting, despite all, to provide support to the trainees, to the pragmatic position of accepting the sub-optimal contract's conditions and keeping one's business alive.

\section{Responsibility Towards the Client or the Trainee?}

In practice, the arrangement of the majority of intercultural interventions is very similar. The organisation takes financial responsibility for the training in which employees receive knowledge and develop skills within a given domain. Thus, the contractor is the organisation; however, the beneficiaries are the trainees. What happens when interculturalists believe the interest of the latter is not well served in the program for which the organisation is willing to pay? Should they be loyal to the sponsor of the intervention or to the individuals that are directly affected by the program? When confronted during a SIETAR 2007 USA workshop on 'ethical standards in intercultural work' with the question 'whom do you serve during a training session: the organisation or the employee?' The trainers sighed and one of them responded contemplatively: 'This is a very good question...'

\section{Where Does the Responsibility Stop?}

Interculturalists' challenges regarding the limit of their responsibility are complex. For example, an activist in a training session (SIETAR USA 2011) was pondering the difficulty of drawing boundaries in her contractual relationship with the client, not only to terminate the contract (and get paid) but also to empower her client to free herself from the relationship. Julie, the entrepreneur, said: 'To me, 
there is no ethical question: as long as there is a need, I have no problem going in'. In other words, some interculturalists wonder how to render the client autonomous and develop his or her intercultural skills so the trainer is no longer needed; others see a sustainable source of incomes in such dependency. Discussions on where to draw the line of responsibility (and intervention) with the client take place in various settings and generate mixed opinions among the interculturalists.

Some interculturalists fear that the knowledge they bring forward for a better understanding of the other may, in fact, be used to serve manipulative ambitions or contribute to more exploitation. This is another aspect of the struggle. For example, a professor in the 'Eye on Ethics' forum stresses that the moral obligation of interculturalists is to ponder who will benefit from the training

Nor have I heard anyone say we are gaining skills and strategies so we can be more efficient in exploiting those who are positioned with less power than us. Yet, I know this is happening as a result of our work. I am aware of examples in community-based work, corporate settings, universities, and the military [...] where training and research in intercultural communication has been used for exploitative and dehumanizing purposes.

The trainer's accountability towards society at large is another dimension of the theme pertaining to the boundary of responsibility. In the SIETAR USA 2011 conference session on ethics, entrepreneur John reflected on a recent job he did for the US Corporation relocating parts of its operations abroad.

What we do, it is making it easier for these companies to make the same in another location [and thus leading to local unemployment], but my fiancée is a social worker and she deals with poverty all day (...).

My balancing? I teach for corporations-and if I don't, other will do it—and I support a social worker.

These discussions reveal that, for some, interculturalists' perceived responsibility goes beyond the trainees and the client; it extends to those who may be manoeuvred into a contract, or an exploitative relationship, by the trainee who is now equipped with intercultural skills and, thus, better able to function in a culturally foreign environment. This also extends to those who may lose their job locally because it becomes easier for companies to have effective relocations overseas.

In sum, the recurrence of conversations on topics related to responsibility is three-fold. First, interculturalists feel responsible to deliver a particular content: a minimum quality they believe is needed to reach the goals of personal growth, transformational change, intercultural awareness, and intercultural sensitivity for the trainees (Berardo 2008). They have different preferences regarding which techniques to use to reach these goals, yet they need to be able to address the agenda of a company if they are to train its employees; this condition is necessary to sustain the intercultural business. Such dynamics create tension between serving the interest of the trainees and those of the contractor. This is the second aspect that is highlighted by these conversations: the interculturalists feel the responsibility towards their own business and towards the beneficiaries of their trainees; however, perhaps not primarily towards their clients. Third, the dilemmas regarding the boundaries of responsibility and the discussions that follow indicate that interculturalists generally reflect upon their responsibility towards the other: as human beings that should be treated with dignity. This is to say, interculturalists' conversations about these dilemmas are indicative of their views of the others and their perceived responsibility towards society or humanity at large-not only towards their client. They also reveal that not all interculturalists think that addressing their clients' needs leads to being ethical.

The profile of the interculturalists may influence their position regarding the topic. In our experience, successful trainers (gurus or entrepreneurs) have mostly solved their struggles regarding training content. The activists appear to be those who are less experienced in dealing with corporate contexts and who may tend to defend 'idealist' positions, sometimes clearly linked to ideological or ethical grounds. Entrepreneurs present the broadest range of positions on the topics.

\section{Interculturalists' Struggles Indicate a Professional Ethical Identity}

We argue here that the concerns interculturalists express about their commercial relationships are indicative of a collective image they have of themselves (a form of professional identity) and of their clients. In the previous section, we saw that the community feels responsible for a particular content: personal growth, transformational experience, intercultural awareness, and sensitivity (Berardo 2008). However, some see their clients as hampering the realisation of 'good' training content with their corporate concerns of return on investment or effectiveness and impact. In addition, conversations denote that some interculturalists feel limited responsibility to the client firm. As long as they can keep their own business going, some have expressed a preference of responsibility towards the beneficiaries of their training: the trainees, the persons, and not the organisation. Finally, interculturalists discuss the possibility that the knowledge they diffuse can be used for 
manipulative or exploitative purposes, while the claimed purpose of the intercultural community is the contribution to better understanding between people (see below). This reveals a suspicious or critical stance towards clients and clients' objectives.

We argue the reasons for such a relationship and view of their client is linked with the self-portrayal interculturalists sketch of themselves when they actively construct their image (conference programs, websites, internal communications) and in differentiation talks, where they tend to present themselves in opposition to another. We show that in collective conversations this 'other' (thus the one who the interculturalists are not) is precisely their client, or briefly said: the corporate environment.

\section{The Claimed Humanist Identity of the Group}

Intercultural dialogue and building bridges between people from different backgrounds is at the core of the advanced community's ideal (or ideology) in its selfportrayal (Pusch 2004) and in official statements. Main themes with which interculturalists work include cultural awareness, mutual understanding, social justice, and even world peace. The intercultural work as well as the organisation SIETAR has their roots in foreign student services and Peace Corps work (Dahlén 1997; Pusch 2004). SIETAR asserts in its mission and vision statements its adherence to humanist and pacifist principles. For example, SIETAR USA (2008) 'believe(s) that we must all work towards effective and peaceful relations among the peoples of the world (...) It is a collective work that requires the efforts of many caring and concerned individuals'. The Intercultural Communication Institute, with its tight connections with SIETAR communities, insisted in its 2012 New Year's greetings to 'contribute to deeper understanding and reduced conflict among peoples of different cultures'. SIETAR Europa (2011) 'subscribes to the Universal Declaration of Human Rights and works towards the elimination of every kind of discrimination'. The focal point of the conferences (e.g. 'Human Rights' for SIETAR France 2010 annual meeting), the keynote speakers, and round tables can be linked to persons or organisations involved in resistance to oppression, human rights activism, or anti-racial movements. In SIETAR, these references to meta-discourses on tolerance, integration, and resistance to injustice express the idea that interculturalists have a mission to fulfil spreading the word of intercultural communication to make the world a better place to live in' (Dahlén 1997, p. 41). The humanist ethos of the interculturalists constantly transpires in workshops and collective conversations and is presented as an 'ideal', as expressed in the following quote:
When we have diversity and respect, this makes for synergy and creative solutions. Perhaps we all, as citizens of the world, should be concerned about becoming actively involved in challenging oppression, wherever we see it, be it in the form of economic exploitation or even down to standing up for a colleague who is being bullied at work. Rose, entrepreneur (DIP)

In sum, we argue that, with such claims and discursive constructions, the group is developing not only an identity but also more specifically cultivating an ethical identity that places strong emphasis upon humanist ethos with the themes of responsibility towards the other, understanding, and respect. This characteristic of the professional group is both 'distinguished' (Whetten 2006, p. 223) and also, as we show next, distinguishing.

\section{Who the Interculturalists Say They 'Are Not'}

When narrating her numerous years of experience in SIETAR France and Europa, entrepreneur Marie-Claire commented in 2010: 'In the beginning it was tripartite: one-third of researchers, one-third HRM [Human Resource Management practitioners] and one-third consultants or coaches. Now, all HRM people are gone'. There were few direct representatives of the corporate context currently present in the SIETAR events we attended. As a result, the corporate context is neither directly nor strongly represented among the interculturalists. Rather, it is represented by few HRM representatives, and by interculturalists who work much with corporations such as successful entrepreneurs or gurus. If we focus upon collective conversations such as workshops or conference sessions, the portrait they sketch of the corporate context or corporate HRM appears interestingly coherent, thus, indicating a form of collective identity discourse. This corporate context is outlined as instrumental and is in opposition to the interculturalists' humanist ethos.

During the SIETAR Europa 2011 congress, the head of the famous corporate training centre of a large multinational company described the philosophy behind their intercultural training: 'Everything we do has to be linked to (have an) impact on the products, impact on sales [...] and we measure this'. He later on summarised the changes in the field of intercultural training over the past 10 years, and dramatised by stating: 'Now [interculturalists] need to be hyper professional, [it has changed] from Kultur Romantik to professionals oriented toward business and results'. The session facilitator at the SIETAR USA 2011 conference session on diversity and global leadership who works in the North American HRM department of a well-known multi-national corporation explained in detail how to adopt 
a corporate narrative. She devoted time to show the contrast between the audience's spontaneous association of 'diversity and global leadership' with words such as 'acceptance', 'understanding', 'inclusion', 'synergy', and 'multiple viewpoints'. She recommended using the ideas and terminology of 'compliance', 'representation', 'employees' attraction and retention', 'employees' productivity', 'innovation' and 'corporate image' instead. She argued that these principles reflect the reality of corporate HRM and should serve as a guide for selling intercultural products within the corporate context.

Famous interculturalists too, especially gurus, partake in the diffusion of this instrumental image of HRM. Some have been very successful at developing their own training material, training models, or measurement tools that they sell to companies and other interculturalists through accreditation trainings. During a training session at the SIETAR USA 2007 conference on interculturalists' work with companies, a guru explicitly addressed the theme of cultural awareness: one of the core distinctive missions that interculturalists perceive they have (Berardo 2008), and authoritatively opposed it to a corporate logic: 'You should not make people [culturally] aware. You have to make them effective'. Another interculturalist among the gurus explained at a conference workshop (SIETAR USA 2011): 'We have to have the [cultural] insights, but also the means to show corporations that, given our insights, they can get to their goals faster or cheaper'. Training provided by an upcoming European trainer (entrepreneur) during a SIETAR France event (2010) devoted a half-day session to the difficulty of combining both the 'idealist' views on the intercultural work ('anti-discrimination', 'human rights', 'equality') and what can be called strategic HRM ('competences', 'benefits', 'business case'). The trainer's rationalisation recommended the participants keep these two notions separate or, even better, not mention the idealist view since the terms are 'so loaded (...); they create a big smoke screen' and can jeopardise the conversation with corporate clients and, therefore, the training.

We call 'privileged voices' those who are seen as knowing the corporate conditions and are viewed as being an authority, and given prominence in discussions. These voices can sketch a picture of commercial business environment with traits of return on investment or employee performance. Some interculturalists perceive these traits as standing in opposition to their convictions. During a preconference workshop (SIETAR USA 2011 Master workshop), an activist specialising in diversity management, who attended the session to professionalise her business, said: 'It would feel like selling my soul to use words like bottom line, profit, and return on investment'. If she were to address private clients, she faces the assumed necessity to fit into the instrumentalist logic depicted by HRM representatives and the gurus. Her comment triggered mixed reactions in the room. Some appeared to find her convictions exemplary, while an entrepreneur replied: 'This is just packaging'.

In brief, during collective conversations, the corporate environment is depicted in terms that are explicitly placed in opposition to that in which the community says it stands. This representation of the corporate environment is most perceptible in collective conversations. However, encounters with the corporate environment can be presented very differently during private exchanges. For example, Karoliina is a successful entrepreneur using narrative analysis as a training technique. Her strategic positioning contrasts that, which the corporate environment is said to welcome: namely, intercultural measurement tools and assessment techniques. 'I am doing fine, in fact... I have had my business for seven years now. (...) I have different kinds of clients, being the [culture] specialist for a training agency. Some of [my clients] are big Finnish corporations'.

In sum, there are collective statements and conversations about the interculturalists, who they are, what they stand for (humanism), and from whom they differ. These conversations tend to sketch a one-sided and homogeneous portrait of the corporate context, with dominant instrumental traits put in opposition to the principles of human development that the intercultural community officially supports. In other words, there is a form of professional ethical identity, and this identity is perceptible in the struggles that are discussed among interculturalists regarding the theme of responsibility. Consequently, an ethical identity of the professional community precedes and partakes in the ethicalisation process of the group, as we will now discuss in more detail.

\section{Discussion}

First of all, it is necessary to reposition the case in the broader literature on code of ethics. The approach taken by SIETAR is indicative of a will to develop a pro-active or high-road (Rezaee et al. 2001) stance to code of ethics development. This approach wishes to start a participative process for the development of a code of ethics or 'inspirational guidelines'. The SIETAR organisation (SIETAR USA board) visibly initiates and supports this, as do some of the gurus (SIETAR conference sessions) and professors (forum discussions on ethics). Therefore, our study supports Fukukawa et al.'s (2007) argument that the 'ethicalization' process starts with leadership, coercion from external forces, or as a strategy. In this case, the process lies with the leadership of interculturalists in influential positions (professors and gurus and, for SIETAR USA, the board as well). This may also indicate a stronger concern in 
the North American environments for the articulation of explicit codes of ethics (Matten and Moon 2008) since, among all the SIETAR organisations, only SIETAR USA is currently working on the development of 'inspirational guidelines'.

Interculturalists' Views on the Corporate World Influencing Their Responsibility Struggles

Messikomer and Cirka (2010) started the development process of a code of ethics with the consultation of members of the professional community asking about the ethical struggles they face in their work activities. In the SIETAR case as well, participants are asked to share their concerns. Among the various ethical struggles that are voiced during collective conversations, we considered the one related to responsibility. The struggles illustrate the same concerns of responsibility as expressed in most corporate codes of ethics studied by Gaumnitz and Lere (2002, p. 43). The first one touches upon the responsibility 'to use full knowledge and ability to perform'. The interculturalists discuss the difficulty to sell a service that can truly operationalise their full knowledge and ability to perform since the contractual conditions that are offered are sometimes as short as a telephone conversation. Interculturalists talk about how they can be torn between an ideal content of, for example, creating the conditions for a transformative learning for their participants and the restricted format that is given to them. However, some feel they need to accept these constraints for the survival of their business, and also because they may tend to believe that this is what corporate conditions are about; this is especially true for young entrepreneurs and activists. Thus, the instrumental, performance, and profit-oriented portrait that are sketched can explain the ethical dilemma expressed by the junior interculturalists in the collective conversations in which the corporate world is depicted. They feel the ethical responsibility to perform, but their view (and perhaps their limited experience) of the corporate client may lead to impede this performance. This viewpoint partly comes from the collective conversations where gurus and successful entrepreneurs have a privileged voice, as the ones training the community and whose opinions are presented as being the authority. Worth noting is that, for some, these privileged voices are behind the popular intercultural tools that are said to be appreciated by the corporate environment.

The second element of responsibility that codes of ethics state is 'to support the objectives of the client' (Gaumnitz and Lere 2002, p. 43). Here again, the constructed collective view of the corporate environment can provide some explanation of the struggles. As we saw, a collective discourse tends to differentiate between the community's priorities and those of the corporate world. Corporations are said to represent performance, maximise employee productivity, effectiveness, and fast (and perhaps cheap) goal achievements. In contrast, interculturalists are said to represent values of humanism such as understanding, care, and dialogue. Thus, the client's objectives are seen as opposite those that humanism has at heart. This can explain why some interculturalists tend to express a responsibility towards the beneficiaries of their training, rather than the client organisation buying the service. This is an ethical tension since the organisation is eventually the client, and not the trainee.

Finally, the third aspect regarding responsibility present in the majority of the codes of ethics is linked to the 'obligation not to aid unethical behavior' (Gaumnitz and Lere 2002, p. 43). Similarly, some interculturalists face an ethical struggle. Corporations' objectives of the training can be against the interests of some employees. Since interculturalists' collective view of the corporate environment may depict it as an instrumental place, the struggles that some interculturalists feel regarding serving the interest of the client are reinforced.

In other words, the claimed humanist ethos of the community and its identity (construction) that stands in opposition to an image of the corporate environment are two elements that can explain the way interculturalists discuss responsibility struggles. For example, entrepreneurs do not seem to see HRM functions as partners in their work, and do not seem to see them as driven by a humanist ethos. To that extent, they are rejoining critical studies that claim a lack of humanity in HRM practices and ideology (e.g. Townley 1993; Greenwood 2002; Delbridge and Keenoy 2010). Some HRM representatives are present in collective conversations; they too portray the corporate environment in contrast to the humanist discourse and terminologies. They support the view of HRM as aligned with bottom line, which seems to reflect a concern for a more strategic inscription of HRM in corporate strategies (Yao-Sheng 2005) and, as some argue, against the interests of employees (Van Buren et al. 2011; Kochan 2007). In sum, the description of the corporate environment in opposite terms to the ones describing the intercultural community may be the outcome of the combination of two elements: the shift of the HRM function towards a more strategic positioning in organisations and an identity differentiation process.

The identity differentiation that interculturalists make between themselves and the other (in this case, the corporate world) illustrates what Ybema et al. (2009) call self-other identity talk: a critical element in identity construction. This may indicate that the group is 'doing' identity during collective conversations, by portraying itself as being different from an 'other'. These linguistic binary oppositions are also used to establish a hierarchical 
relationship with the other (Ainsworth and Hardy 2004). Although it is not so explicitly stated, there seems to be an ethical hierarchical relationship here between a desirable humanist ethos and a vile instrumental corporate logic. Identity discourses are also linked to a power relationship; they legitimise or challenge it (Ball and Wilson 2000). We can argue that the weak power stance of the interculturalists (especially the entrepreneurs and activists) is compensated by a perceived higher ethical identity. As one entrepreneur said, 'it would feel like selling my soul to use words like bottom line, profit, and return on investment'. In other words, she indicated a distinct (and implicitly higher) ethical standard than that of the 'instrumentalist business case' (Noon 2007).

The ethical identity construction of the interculturalists, in particular, when it is articulated in contrast to corporate contexts, can explain the ethical struggles around the notions of responsibility. This explicates the difficulty perceived by the interculturalists to fully perform, to serve their client's objectives and, for some, to avoid doing harm. This also sheds light upon the fact that some interculturalists expressed a feeling of responsibility towards their trainees, rather than their clients.

\section{A Form of Ethical Identity Prior to an Ethicalisation Process}

This form of professional ethical identity influences the kind of struggles interculturalists explore in conversations about responsibility: the kind of conversations that are a first step in the participative code of ethics development (Messikomer and Cirka 2010). This means that professional ethical identity can influence the code of ethics content. Consequently, we are presented with a reverse relationship between code of ethics and ethical identity as the one argued in the literature, especially by Verbos et al. (2007) and Webley and Werner (2008) where codes are said to prime ethical identity.

SIETAR organisations may not have a code of ethics, yet the community states a humanist ethos that is most strongly perceptible through mission statements and conferences. This can be associated with what Berrone et al. (2007, p. 36) call 'revealed ethics', which communicates ethical attitudes and beliefs of the professional group, and which is a component of ethical identity. In other words, the presence of a form of professional ethical identity, together with the presence of a form of revealed ethics prior to the development of a code of ethics and, thus, prior to a formal ethicalisation process, questions the current link argued in the literature regarding ethicalisation and ethical identity.

Tentative explanation of this reversed relationship can be found in organisational identity dynamics studies (e.g.
Gioia et al. 2010; Clegg et al. 2007; Ybema 2010). Gioia et al. (2010) realised how organisational identity is created in interplay between two components. The first are individual actors' social meaning constructions of who we are as an organisation (e.g. Gioia et al. 2000). The second are the organisation's identity claims (Whetten, 2006) that are, on the entity-level, self-positioning commitment, and actions (e.g. Corley et al. 2006). If such a process is transferable to a professional ethical identity development, it is possible that individual meaning constructions of what it is to be an 'ethical' interculturalist are in interplay with what SIETAR organisations claim they are. Could it be that interculturalists with a humanist ethos feel comfortable within SIETAR organisations to express this ethos as a reference (e.g. in collective discussion, in trainings, in informal conversations during the networking activities)? Could it be that SIETAR organisations might have built upon it, reinforcing it with their written statements (mission statements, conference program)? This can explain the presence of 'revealed ethics' without even a code of ethics. It can also explain the presence of a form of professional ethical identity perceptible during collective conversations where collective social meanings are most apparent.

The interplay between individual and organisational claims is likely to influence the codification and utilisation of the 'inspirational guidelines' that SIETAR USA is currently developing. This is an interesting situation in view of the discussion on code effectiveness. SIETARians are not only taking part in the development of inspirational guidelines (Schwartz 2002) but also explicitly codifying their own humanist ethical stance regarding responsibility, and their relationship with others. In consequence, it is most probable that they will follow these guidelines. The struggles identified among the interculturalists press them to make a decision: they create a place for humanist ethics of 'being responsible for the Other' in Lévinas' terms (Bevan and Corvellec 2007), and for interculturalists to become moral subjects, rather than moral agents applying the rules of a code of conduct (Jones 2003; ten Bos 1997). This leads to what many would call an effective code of ethics. The existence of this form of ethical identity preceding the codification of guidelines might also be necessary to avoid 'calculating ethics' (Jones 2003). In the case of SIETAR, it is possible that the community is going to develop what Bevan and Corvellec (2007) call managerial ethics based on individuals' concerns and responsibility for otherness, or a questioning code (Painter-Morland 2010).

The humanist ethos of the intercultural community is thus playing an influential role in the development of its code of ethics. However, it does not mean that all the interculturalists share this ethos. Although interculturalists of various profiles joined the conversations about the theme of responsibility, they certainly did not deal with the 
struggles in the same way. Next to a humanist discourse, some adopt more pragmatic answers to secure revenues from their intercultural business. In addition, some maintain that they face no struggles regarding content and the responsibility to perform. Considering the internal variations of ethical stances in more depth and breadth, we might realise that the intercultural community has a plural ethical identity (such as organisational identities, e.g. Elsbach and Kramer 1996; Sillince and Brown 2009). However, a form of professional ethical identity is tangible in collective conversations, especially in contrast to the homogenising discourse that is advanced about the (ethical identity) of the corporate environment.

Eventually, the existence of a form of ethical identity influencing code development poses a question regarding the theme of business ethics and codification. When Jones (2003) and ten Bos (1997) discuss individuals' relationship to (moral) rules, they do not consider the possibility that these rules can be the formalisation of the individual's own ethical stance. What kind of ethics is it when individuals choose to subject themselves to their own rules, as this could be the case for some in the SIETAR community?

\section{Conclusion}

The outcomes of this study contribute to the ongoing conversation about the 'ethicalization' process (Fukukawa et al. 2007) of organisations or professional groups: particularly, the investigation of the link between code of ethics and ethical identity. This article has two primary contributions to the domain of ethical identity construction. The first reveals a more reciprocal relationship between ethical identity and ethicalisation processes, such as the development of a code of ethics. The second indicates that ethical identity construction may be subjected to the same mechanisms as organisational identity construction and, more specifically, self-other identity talks (Ybema et al. 2009).

The first contribution is two-fold. First, our investigation reveals that there is a form of professional ethical identity prior to a formal ethicalisation process (Fukukawa et al. 2007) of the professional group. Although implicit, this professional identity is sufficiently tangible to the community to influence interculturalists' perceptions of their mission and how and what they want to bring to their clients. Therefore, we argue that the ethicalisation process may not be as linear as currently claimed in the literature (see Verbos et al. 2007; Webley and Werner 2008). For example, Verbos et al. (2007, p. 22) argue that organisational ethical identity is the result of 'the multiplicative interaction of authentic leadership, aligned organisational processes and an ethical organizational culture' (in which the code of ethics is a part). They see group identity salience as the result of interactions within an organisation (p. 20) and do not consider that employees may bring a specific and influential form of collective ethical identity to the organisation. Put differently, the potential impact that professional ethical identities may have on the development of organisational ethical identity is overlooked in Verbos et al. (2007), and generally in the organisational ethical identity literature.

Second, we show that professional ethical identity directly influences the ethical dilemmas that the interculturalists tend to voice in conversations about ethics. These struggles can impact the content and effectiveness of codes of ethics if the codes are developed in a participative process. However, the literature currently considers only how codes of ethics participate in ethical identity development, and overlooks how existing ethical identity can impact code development.

As an example, Messikomer and Cirka's (2010) work on professional ethical identity addresses specifically code of ethics development. The authors do not show a concern for the internal diversity of the professional group that they investigate; instead, they follow Newton's (1994) framework: a pre-occupation for what professionals have in common and a close relationship with the community leader (p. 61). In the case of the interculturalists, we show that the ethical struggles expressed by workshop participants are linked to a form of pre-existing ethical identity that is influenced by privileged voices. In addition, depending upon interculturalists' profiles, the encountered struggles were different, with responsibility dilemma touching most strongly the junior interculturalists. This points to a complex relationship between privileged voices (e.g. leadership), ethical struggles, and the development of code of ethics: a relationship different from that, which primarily places leadership in a key facilitating position (see, e.g. Verbos et al. 2007; Fukukawa et al. 2007; Webley and Werner 2008; Newton 1994).

Additional studies need to further investigate the link between professional ethical identity, privileged voices, and codes of ethics. For example, if a form of ethical identity precedes a formal ethicalisation process, it should be taken into consideration in the study of the process. Currently, many studies implicitly adopt the assumption that there is no form of group ethical identity prior to the start of an ethicalisation process (this is explicitly articulated in Verbos et al. 2007, p. 20). The investigation of participative code of ethics development could consider first existing ethical identity talks, their relationship to leadership, and whether they influence the struggles that employees face. Other studies could further investigate whether the ethical identity that exists prior to the ethicalisation process radically transforms, or whether it contributes to reinforcing itself 
because it influences the code of ethics content. In addition, complementary studies may consider the relationship between leadership (or some other privileged voices) and whether the ethicalisation process reinforces or underpins their positions.

The second contribution of this article is the theme of ethical identity construction. The extant literature tends to study ethical identity of firms on the level of the firm's entity. Fukukawa et al. (2007, p. 4) operate the distinction between 'corporate ethical identity studies' and 'organisational ethical identity studies'. The former group of studies has an entity-level focus and investigates the firm's ethical claims, behaviour, and its relationship with stakeholders (Berrone et al. 2007). The latter studies have an internal employee focus (Messikomer and Cirka 2010; Verbos et al. 2007; Baker and Roberts 2011). In our study, we investigated social meanings expressed during collective conversations within the SIETAR community and during professional trainings. This means that we adopted an internal locus of analysis. This enabled us to identify the presence of self-other identity talks that are considered as key components in organisational identity construction (Ybema et al. 2009). In other words, we found an ethical identity construction process that seems to need to define an 'other' to define oneself. For some, the other in our empirical case was depicted as a (less) ethical other. To our knowledge, this differentiation process has not been reported, particularly, the portraying of an ethical other in the ethical identity construction process. Following the recommendations of Gioia et al. (2010), we could develop studies on the ethical identity development process simultaneously adopting the perspective of the firm level and an internal locus of investigation. This shall further our understanding of how phenomena within the firm and at the firm level interact in the development of ethical identity.

\begin{abstract}
Acknowledgments The authors gratefully acknowledge the very insightful and constructive feedback provided by Michelle Greenwood, Jan Schapper and Gavin Jack as the editorial team that followed our submission. Their work as well as the stimulating comments by the anonymous reviewers contributed significantly to further develop and refine our argument. This article is part of the research project 'The hidden side of cross-cultural management', generously financed by the Swedish Research Council, Vetenskapsrådet (412-2009-2020). The authors are also thankful to the University of Sydney that financially supported Laurence as a guest researcher in the finalization phase of the article.
\end{abstract}

Open Access This article is distributed under the terms of the Creative Commons Attribution License which permits any use, distribution, and reproduction in any medium, provided the original author(s) and the source are credited.

\section{References}

Adam, A. M., \& Rachman-Moore, D. (2004). The methods used to implement an ethical code of conduct and employee attitudes. Journal of Business Ethics, 54(3), 223-242.
Agar, M. H. (1996). The professional stranger: An informal introduction to ethnography (2nd ed.). San Diego: Academic Press.

Ainsworth, S., \& Hardy, C. (2004). Discourse and identities. In D. Grant, T. Keenoy, \& C. Oswick (Eds.), Handbook of organizational discourse (pp. 153-173). London: SAGE.

Albert, S., \& Whetten, D. A. (1985). Organizational identity. Research in Organizational Behavior, 7, 263-295.

Alvesson, M., \& Deetz, S. (2000). Doing critical management research. London: SAGE.

Alvesson, M., \& Sköldberg, K. (2000). Reflexive methodology. New vistas for qualitative research. London: SAGE.

Ashman, I., \& Winstanley, D. (2007). For or against corporate identity? Personification and the problem of moral agency. Journal of Business Ethics, 76, 83-95.

Baker, M., \& Roberts, J. (2011). All in the mind? Ethical identity and the allure of corporate responsibility. Journal of Business Ethics, $101,5-15$.

Ball, K., \& Wilson, D. (2000). Power, control and computer-based performance monitoring: Repertoires, resistance and subjectivities. Organization Studies, 21(3), 539-565.

Balmer, J. M. T., \& Soenen, G. B. (1999). The acid test of corporate identity management. Journal of Marketing Management, 15, 69-92.

Balmer, J. M. T., Fukukawa, K., \& Gray, E. R. (2007). The nature and management of ethical corporate identity: A commentary on corporate identity, corporate social responsibility and ethics. Journal of Business Ethics, 76, 7-15.

Barmeyer, C., \& Davoine, E. (2011). The intercultural challenges in the transfer of codes of conduct from the US to Europe. In H. Primecz, L. Romani, \& S. Sackmann (Eds.), Cross-cultural management in practice: Culture and negotiated meanings (pp. 53-63). Cheltenham: Edward Elgar.

Berardo, K. (2008). The intercultural profession in 2007: profile, practices, challenges. Retrieved June 29, 2011 from http://www.sietareu.org/what-is-sietar/facts-and-figures.

Berrone, P., Surroca, J., \& Tribó, J. A. (2007). Corporate ethical identity as a determinant of firm performance: A test of the mediating role of stakeholder satisfaction. Journal of Business Ethics, 76, 35-53.

Bevan, D., \& Corvellec, H. (2007). The impossibility of corporate ethics: For a Levinasian approach to managerial ethics. Business Ethics: A European Review, 16(3), 208-219.

Brickson, S. L. (2005). Organizational identity orientation: Forging a link between organizational identity and organizations' relations with stakeholders. Administrative Science Quarterly, 50, 576-609.

Chouliaraki, L., \& Fairclough, N. (1999). Discourse in late modernity: Rethinking critical discourse analysis. Edinburgh: Edinburgh University Press.

Chreim, S. (2005). The continuity-change duality in narrative texts of organizational identity. Journal of Management Studies, 42, 567-593.

Cleek, M. A., \& Leonard, S. L. (1998). Can corporate codes of ethics influence behavior? Journal of Business Ethics, 17(6), 619-630.

Clegg, S. R., Rhodes, C., \& Kornberger, M. (2007). Desperately seeking legitimacy: Organizational identity and emerging industries. Organization Studies, 28(4), 495-513.

Corley, K. G., Harquail, C. V., Pratt, M. G., Glynn, M. A., Fiol, C. M., \& Hatch, M. J. (2006). Guiding organizational identity through aged adolescence. Journal of Management Inquiry, 15, 85-99.

Czarniawska, B. (1997). Narrating the organization: Dramas of institutional identity. Chicago: University of Chicago Press.

Dahlén, T. (1997). Among the Interculturalists: An emergent profession and its packaging of knowledge. Stockholm: Almqvist and Wiksell International.

Delbridge, R., \& Keenoy, T. (2010). Beyond managerialism? International Journal of Human Resource Management, 21(6), 799-817. 
Elsbach, K. D., \& Kramer, R. M. (1996). Members' responses to organizational identity threats: Encountering and countering the Business Week rankings. Administrative Science Quarterly, 41, 442-476.

Emerson, R. M., Fretz, R. I., \& Shaw, L. L. (1995). Writing ethnographic fieldnotes. Chicago: University of Chicago Press.

Fairclough, N. (2001). The discourse of new labour: Critical discourse analysis. In M. Wetherell, S. Taylor, \& S. Yates (Eds.), Discourse as data: A guide for analysis (pp. 229-266). London: SAGE.

Fairclough, N., \& Wodak, R. (1997). Critical discourse analysis. In T. A. van Dijk (Ed.), Introduction to discourse studies (pp. 258-284). London: SAGE.

Fukukawa, K., Balmer, J. M. T., \& Gray, E. (2007). Mapping the interface between corporate identity, ethics and corporate social responsibility. Journal of Business Ethics, 76, 1-5.

Gaumnitz, B. R., \& Lere, J. C. (2002). Contents of codes of ethics of professional business organizations in the United States. Journal of Business Ethics, 35(1), 35-49.

Gioia, D. A., Schultz, M., \& Corley, K. G. (2000). Organizational identity, image, and adaptive instability. Academy of Management Review, 25, 63-81.

Gioia, D. A., Price, K. N., Hamilton, A. L., \& Thomas, J. B. (2010). Forging an identity: An insider-outsider study of processes involved in the formation of organizational identity. Administrative Science Quarterly, 55, 1-46.

Gordon, K., \& Miyake, M. (2001). Business approaches to combating bribery: A study of codes of conduct. Journal of Business Ethics, 34, 161-173.

Gray, E. R., \& Balmer, J. M. T. (2001). Ethical identity: What is it? What of it? Bradford University School of Management Working Paper, 01/15.

Greenwood, M. (2002). Ethics and HRM: A review and conceptual analysis. Journal of Business Ethics, 36(3), 261-278.

Gunawardena, C., Lowe, C., \& Anderson, T. (1997). Analysis of a global on-line debate and the development of an interaction analysis model for examining social construction of knowledge in computer conferencing. Journal of Educational Computing Research, 17(4), 395-429.

Haniffa, R., \& Hudaib, M. (2007). Exploring the ethical identity of Islamic banks via communication in annual reports. Journal of Business Ethics, 76, 97-116.

Helin, S., \& Sandström, J. (2007). An inquiry into the study of corporate codes of ethics. Journal of Business Studies, 75, 253-1271.

Helin, S., \& Sandström, J. (2008). Codes, ethics and cross-cultural differences: Stories from the implementation of a corporate code of ethics in a MNC subsidiary. Journal of Business Ethics, 82, 281-291.

Helin, S., \& Sandström, J. (2010). Resisting a corporate code of ethics and the reinforcement of management control. Organization studies, 31(05), 583-604.

Herring, S. (2001). Computer-mediated discourse. In D. Schiffrin, D. Tannen, \& H. E. Hamilton (Eds.), The handbook of discourse analysis (pp. 613-634). Oxford: Blackwell.

Hofstede, G. (1980). Cultures consequences. Beverly Hills: SAGE.

Jensen, T., Sandström, J., \& Helin, S. (2009). Corporate codes of ethics and the bending of moral space. Organization, 16(4), 529-545.

Jones, C. (2003). As if business ethics were possible, 'within such limits'.... Organisation, 10(2), 223-248.

Kaptein, M. (2011). Toward effective codes: Testing the relationship with unethical behavior. Journal of Business Ethics, 99, 233-251.

Kaptein, M., \& Wempe, J. (1998). Twelve Gordian knots when developing an organizational code of ethics. Journal of Business Ethics, 17(8), 853-869.

Kaptein, M., \& Schwartz, M. S. (2007). The effectiveness of business codes: A critical examination of existing studies and the development of an integrated research model. Journal of Business Ethics, 77, 111-127.

King, S. A. (1996). Researching internet communities: Proposed ethical guidelines for the reporting of results. The Information Society, 12, 119-127.

Kochan, T. (2007). Social legitimacy of the HRM profession: A US perspective. In P. Boxall \& J. Purcell (Eds.), The oxford handbook of HRM (pp. 599-619). Oxford: Oxford University Press.

Langlois, C. C., \& Schlegelmilch, B. B. (1990). Do corporate codes of ethics reflect national character? Evidence from Europe and the United States. Journal of Business Studies, 21(4), 519-539.

Lewis, R. D. (1996). When cultures collide. Leading across cultures. Boston: Nicholas Brealey Publishing.

Mahadevan, J. (2001). Engineering culture(s) across sites: Implications for cross-cultural management of emic meanings. In H. Primecz, L. Romani, \& S. Sackmann (Eds.), Cross-cultural management in practice: Culture and negotiated meanings (pp. 89-100). Cheltenham: Edward Elgar.

Marcus, G. (1995). Ethnography in/of the world system: the emergence of multi-sited ethnography. Annual Review of Anthropology, 24(1), 95-117.

Marra, R. M., Moore, J. L., \& Klimczak, A. K. (2004). Content analysis of online discussion forums: A comparative analysis of protocols. Educational Technology Research and Development, 52(2), 23-40.

Martins, L. L. (2005). A model of the effects of reputational rankings on organizational change. Organization Science, 16, 701-720.

Mathews, M. C. (1987). Codes of ethics: Organizational behavior and misbehavior. Research in Corporate Social Performance, 9, 107-130.

Matten, D., \& Moon, J. (2008). Implicit and explicit CSR: A conceptual framework for a comparative understanding of corporate social responsibility. Academy of Management Review, 33(2), 404-424.

Messikomer, C. M., \& Cirka, C. C. (2010). Constructing a code of ethics: An experiential case of a national professional organization. Journal of Business Ethics, 95(1), 55-71.

Montoya, I. D., \& Richard, A. J. (1994). A comparative study of codes of ethics in health care facilities and energy companies. Journal of Business Ethics, 13(9), 713-717.

Munro, R. (1998). Ethics and accounting: The dual technologies of self. In M. Parker (Ed.), Ethics and organizations (pp. 197-220). London: SAGE.

Murthy, D. (2008). Digital ethnography: An examination of the use of new technologies for social research. Sociology, 42(5), 837-855.

Newton, L. H. (1994). The many faces of the corporate code. In L. H. Newton \& M. M. Ford (Eds.), Taking sides: Clashing views on controversial issues in business ethics and society (3rd ed., pp. 81-88). Guildford: Dushkin Publishing Group.

Noon, M. (2007). The fatal flaws of diversity and the business case for ethnic minorities. Work Employment Society, 21(4), 773-784.

Olsen, L. (2004). Making corporate responsibility work: Lessons from real business. Berkhamsted: Ashridge \& British Quality Foundation.

Painter-Morland, M. (2010). Questioning corporate codes of ethics. Business Ethics: A European Review, 19(3), 265-279.

Pratt, M. G., Rockmann, K., \& Kaufmann, J. (2006). Constructing professional identity: The role of work and identity learning cycles in the customization of identity among medical residents. Academy of Management Journal, 49(2), 235-262.

Pusch, M. D. (2004). Intercultural training in historical perspective. In D. Landis, J. M. Bennett, \& M. J. Bennett (Eds.), Handbook of intercultural training (3rd ed., pp. 13-36). Thousand Oaks, CA: SAGE.

Rezaee, Z., Elmore, R. C., \& Szendi, J. Z. (2001). Ethical behavior in higher educational institutions: The role of the code of conduct. Journal of Business Ethics, 30(2), 171-183. 
Romani, L. \& Szkudlarek, B. (2011). To sell and what to sell: Interculturalists' ethical struggle, SIETAR USA forum "Eye on Ethics". http://www.sietarusa.org.

Roth, J. (2009). Editorial, Sofia Congress SIETAR Europa 2007, Selected papers. Retrieved January 16, 2012 from http://www.sietareu.org/ images/stories/documents/sofiapapers.pdf.

Scheitza, A. (2009). Interkulturelle kompetenz: Forschungsansätze, trends und implikationen für interkulturelle trainings. In M. Otten, A. Scheitza, \& A. Cnyrim (Eds.), Interkulturelle kompetenz im wandel. Band 1: Grundlegungen, konzepte und diskurse (pp. 91-119). Münster: LIT Verlag.

Schwartz, M. S. (2002). A code of ethics for corporate code of ethics. Journal of Business Ethics, 41(1-2), 27-43.

Schwartz, M. S. (2004). Effective corporate codes of ethics: Perceptions of code users. Journal of Business Ethics, 55, 323-343.

Schwartz, M. S. (2005). Universal moral values for corporate codes of ethics. Journal of Business Studies, 59, 27-44.

SIETAR USA (2008). About us. Retrieved on June 29, 2011 from http://www.sietarusa.org/Default.aspx?pageId=87312.

SIETAR Europa (2011). Mission. Retrieved June 29, 2011 from http://www.sietareu.org/what-is-sietar/what-is-sietar-2.

Sillince, J. A. A., \& Brown, A. D. (2009). Multiple organizational identities and legitimacy: The rhetoric of police websites. Human Relations, 62(12), 1829-1856.

Singh, J., Carasco, E., Wood, G., \& Callaghan, M. (2005). A comparative study of the content of corporate codes of ethics in Australia, Canada and Sweden. Journal of Business Ethics, 40, 91-109.

Snell, R. S., \& Herndon, N. C. (2004). Hong Kong's code of ethics initiative: Some differences between theory and practice. Journal of Business Ethics, 51(1), 75-89.

Stevens, B. (1994). An analysis of corporate ethical code studies: "Where do we go from here?". Journal of Business Ethics, 13(1), 63-69.

Stevens, B. (2008). Corporate ethical codes: Effective instruments for influencing behavior. Journal of Business Ethics, 78, 601-609.

ten Bos, R. (1997). Essai: Business ethics and Bauman ethics. Organization Studies, 18(6), 997-1014.

Townley, B. (1993). Foucault, power/knowledge, and its relevance for human resource management. Academy of Management Review, 18(3), 518-545.

Trompenaars, F. (1993). Riding the waves of culture: Understanding cultural diversity in business. London: Nicholas Brealey Publishing.

Vaara, E., \& Tienari, J. (2004). Critical discourse analysis as a methodology for international business studies. In R. Marschan-
Piekkari \& C. Welch (Eds.), Handbook of qualitative research methods for international business (pp. 342-359). Cheltenham: Edward Elgar.

Van Buren, H. J., Greenwood, M., \& Sheehan, C. (2011). Strategic human resource management and the decline of employee focus. Human Resource Management Review, 21(3), 209-219.

Van Dijk, T. A. (1997). Discourse as structure and process (Vol. 1). London: SAGE.

Van Dijk, T. A. (2001). Critical discourse analysis. In D. Schiffrin, D. Tannen, \& H. E. Hamilton (Eds.), The handbook of discourse analysis (pp. 352-371). Oxford: Blackwell.

Van Leeuwen, T., \& Wodak, R. (1999). Legitimizing immigration control: A discourse-historical analysis. Discourse Studies, 1(1), 83-118.

Verbos, A. K., Gerard, J. A., Forshey, P. R., Harding, C. S., \& Miller, J. S. (2007). The positive ethical organization: Enacting a living code of ethics and ethical organizational identity. Journal of Business Ethics, 76(1), 17-33.

Weaver, G. R. (2006). Virtue in organizations: Moral identity as a foundation for moral agency. Organization Studies, 27(3), 341-368.

Webley, S., \& Werner, A. (2008). Corporate codes of ethics: Necessary but not sufficient. Business Ethics: A European Review, 17(4), 405-415.

Whetten, D. A. (2006). Albert and Whetten revisited: Strengthening the concept of organizational identity. Journal of Management Inquiry, 15, 219-234.

Winter, R. (2011). The principled legal firm: Insights into the professional ideals and ethical values of partners and lawyers. Journal of Business Ethics, 98, 297-306.

Wodak, R., \& Meyer, M. (2001). Methods of critical discourse analysis. London: SAGE.

Wodak, R., \& Meyer, M. (2009). Methods of critical discourse analysis. London: SAGE.

Yao-Sheng, L. (2005). Business strategy and performance: The role of human resource management control. Personnel Review, 34(3), 294-309.

Yates, S. J. (2001). Researching internet interaction: Sociolinguistics and corpus analysis. In M. Wetherell, S. Taylor, \& S. Yates (Eds.), Discourse as data: A guide for analysis (pp. 93-146). London: SAGE.

Ybema, S. (2010). Talk of change: Temporal contrasts and collective identities. Organization Studies, 31(4), 481-503.

Ybema, S., Keenoy, T., Oswick, C., Beverungen, A., Ellis, N., \& Sabelis, I. (2009). Articulating identities. Human Relations, 62(3), 299-322. 